\title{
CTSV wt Allele
}

National Cancer Institute

\section{Source}

National Cancer Institute. CTSV wt Allele. NCI Thesaurus. Code C114304.

Human CTSV wild-type allele is located in the vicinity of $9 \mathrm{q} 22.2$ and is approximately $10 \mathrm{~kb}$ in length. This allele, which encodes cathepsin L2 protein, is involved in proteolysis. 